The Fourth International Workshop-2009 "Constructive Methods for Non-Linear Boundary-Value Problems"

\author{
Miklós Rontó
}




\title{
THE FOURTH INTERNATIONAL WORKSHOP-2009 “CONSTRUCTIVE METHODS FOR NON-LINEAR BOUNDARY-VALUE PROBLEMS"
}

\author{
MIKLÓS RONTÓ
}

\author{
Received 18 September, 2009
}

In the period from 1th to 4th July, 2009, the Fourth International Workshop-2009

"Constructive methods for non-linear boundary-value problems"

had taken place in Eger, Hungary. The workshop was organized by the Institute of Mathematics of the University of Miskolc, Institute of Mathematics and Informatics of the Eszterházy Károly College in Eger, and Institute of Mathematics of the Academy of Sciences of the Czech Republic in cooperation with the Regional Committee of the Hungarian Academy of Sciences in Miskolc.

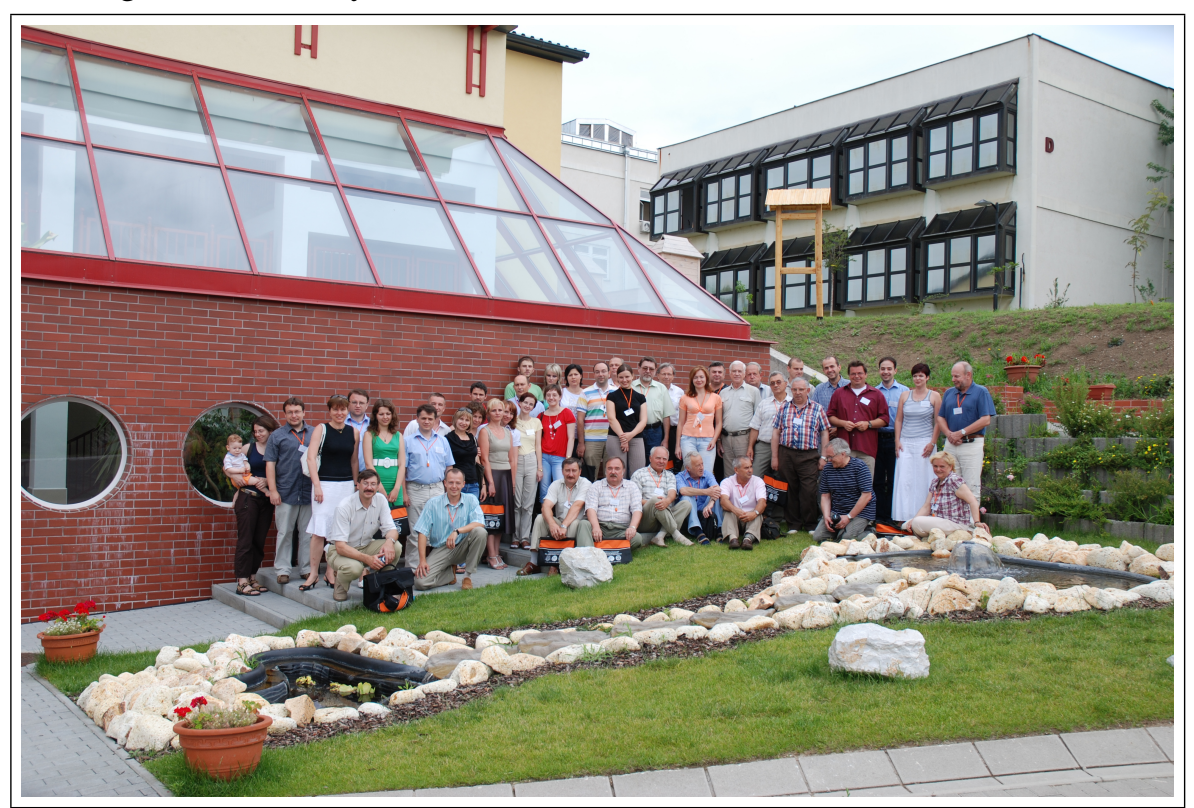

The scope of the conference covered various topics related to the modern theory of boundary value problems in a broad sence, including initial value and periodic problems for functional differential equations, certain boundary value problems for differential equations with homogeneous non-linearities, the method of lower and upper 
functions, bifurcation theory, singular differential equations, limit cycles, difference equations with $p$-Laplacians, the Fučík spectrum, invariant manifolds, stochastic differential equations, impulsive boundary value problems, optimal control problems as well as certain aspects of the theory of generalized differential equations and applications. The workshop was attented by more than 60 researchers from Chile, Israel, Czech Republic, Hungary, Latvia, Romania, Russia, Spain, Slovak Republic, and Ukraine, who held 20 and 30-minute lectures.

The Organizing Committee of the workshop consisting of M. Fečkan, P. Körtesi, K. Liptai, F. Mátyás, V. Marinec, M. Perestyuk, A. Rontó, A. Samoilenko, J. Szigeti, M. Tvrdý, and the author of this note (chairman) gratefully acknowledges the financial support provided by the following funds and institutions:

- Department of Analysis University of Miskolc,

- Faculty of Mechanical Engineering and Informatics, University of Miskolc,

- Tudomány Támogatásáért Észak-Magyarországon Alapítvány.

This meeting was a continuation of the three previous workshops held in Miskolc in 2000 and 2003 and in Sárospatak in 2006.

We hope that the fruitful tradition of this kind of "compact" international meetings oriented at exchange of ideas of researchers working in closely related fields will continue in future.

Author's address

\section{Miklós Rontó}

Department of Analysis, University of Miskolc, 3515 Miskolc-Egyetemváros, Hungary

E-mail address: matronto@gold.uni-miskolc.hu 